\title{
Vaktaalrubriek
}

\section{Alternatiewe indeling by die sistematiek vir drywingselektroniese mutators}

J.D. van Wyk

C.G. Steyn

Departement Elektriese en Elektroniese Ingenieurswese, Randse Afrikaanse Universiteit, Posbus 524, Johannesburg 2000

Met verwysing na twee vorige bydraes aangaande die vaktaal vir Drywingselektronika, ${ }^{1,2}$ word in hierdie bydrae daarop gewys dat daar ook 'n alternatiewe indeling by die sistematiek vir drywingselektroniese mutators gevolg kan word.

Soos met enige sistematiek is daar 'n versameling van moontlikhede. In 'n vak soos die Drywingselektronika - wat binne die Tegniese Wetenskap georden kan word ${ }^{3}$ - moet die verskillende moontlikhede uitgesoek word aan die hand van sinvolheid t.o.v. tegniese objekte en stelsels. ${ }^{3}$ Die alternatief wat tevore bespreek is, het die metode van dowing as kriterium vir klassifikasie gebruik, sodat die elektroniese mutators in die twee families van mutators met natuurlike dowing en met dwingdowing verdeel is. Die volgende vlak van klassifikasie was funksioneel, sodat die vier groepe van natuurlik gedoofde en dwinggedoofde wisselrigters en gelykrigters ontstaan het (figuur 4 van $^{2}$ ).

Die kappers en direkomsetters kan egter in beide groepe mutators ingedeel word. Resonante kappers ${ }^{4}$ maak van lasdowing gebruik, terwyl daar 'n verskeidenheid van direkomsetters bekend is met dwingdowing. ${ }^{5,3}$ Kappers met dwingdowing ${ }^{9}, 10$ en direkomsetters met natuurlike dowing ${ }^{11}$ is reeds lank bekend. As die mutators dus verdeel word aan die hand van stroomgeleidingsprosesse volg die sistematiek soos in figuur 1.

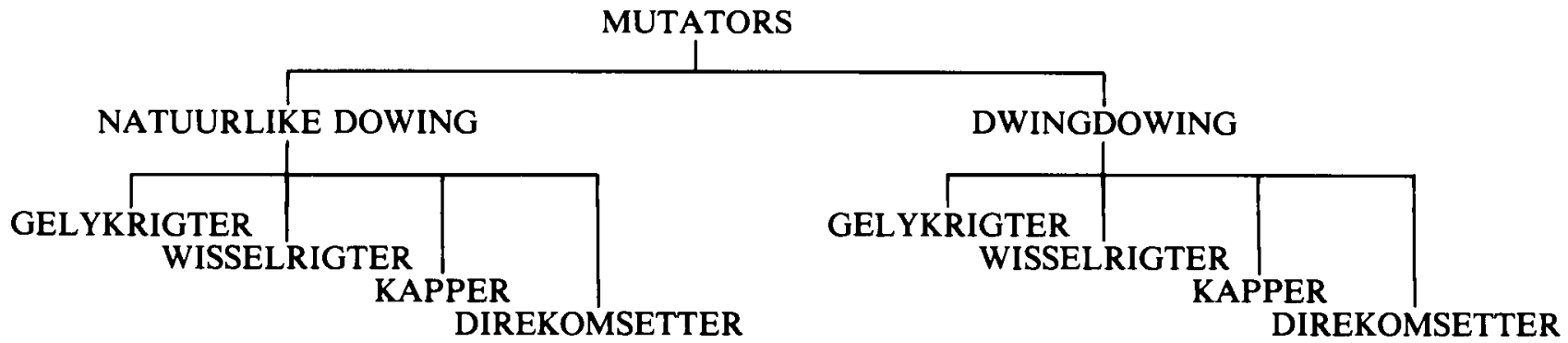

FIGUUR 1: Verdeling van mutators na stroomdowingsproses en funksie

Indien die vlakke van indeling egter omgeruil word, sodat die eerste ordening geskied na funksie en die tweede na stroomgeleidingsproses, word 'n alternatiewe sistematiek verkry, soos in figuur 2.

Die vraag na die voordeel van die tweede alternatief bo die eerste kan met reg gestel word. Dit kan alleen beantwoord word uit die perspektief van die moderne halfgeleiertegnologie.

Die drywingselektronika het sy ontstaan oorspronklik gehad in die beskikbaarheid van die tiratron en kwikdampgelykrigter as elektroniese skakelelemente na 1914.12 Die beperking wat hierdie skakelelemente veral t.o.v. dwingdowing gehad het, het die praktiese daarstelling van baie topologieë beperk. Dit is eers met die koms van die moderne halfgeleiertegnologie en die beskikbaarheid van elektroniese skakelelemente soos tiristors, bilaterale tiristors, asimmetriese tiristors, afskakelbare tiristors en bipolêre drywingstransistors dat 'n hele versameling topologieë 'n praktiese moontlikheid geword het. Die gevolglike ontstaan van direkomsetters met dwingdowing, $5,6,7,8$ van gelykrigters met dwingkommutasie $^{13}$ en die wydverspreide toepassing van pulswydtemodulasietegnieke het gelei tot topologieë waar albei prosesse van dowing in al die funksies van gelykrigters, wisselrigters, kappers en direkomsetters naas mekaar gevind word. 


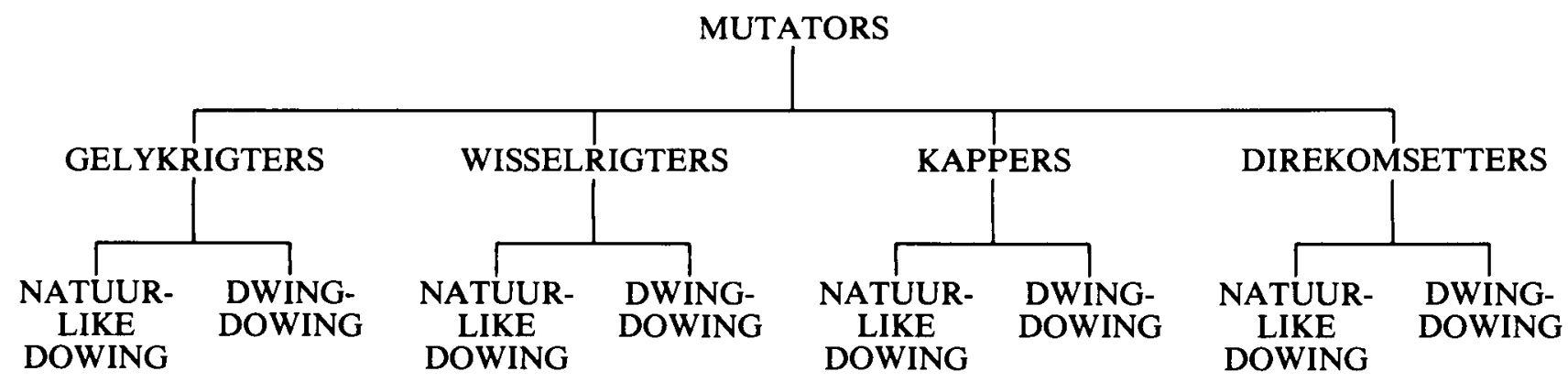

FIGUUR 2: Verdeling van mutaros na funksie en na stroomdowingsproses

Die alternatiewe indeling van figuur 2 is dus volgens ons beter aangepas by die moderne stand van die tegniek in die Drywingselektronika.

\section{VERWYSINGS}

1. Van Wyk, J.D. (1982). Die vaktaal vir Elektronika en Drywingselektronika in Afrikaans, Die Suid-Afrikaanse Tydskrif vir Natuurwetenskap en Tegnologie, 1 (1), Maart 1982, p. 4.

2. Van Wyk, J.D., Steyn, C.G. (1982). Stelselterminologie vir mutators in die Drywingselektronika. Die Suid-Afrikaanse Tydskrif vir Natuurwetenskap en Tegnologie, 1 (1), Maart 1982 , p. 5.

3. Schuurman, E. (1972). Techniek en toekomst (Van Gorcum, Assen).

4. Mapham, N.W. (1967). Low cost ultrasonic frequency inverter using single SCR. IEEE Trans. Ind. Gen. Applic, IGA$3(5), 378-388$.
5. Case, M.J. en Enslin N.C. (1977). A direct ac to ac frequency converter. Trans SAIEE, 68, 211-214.

6. Alexa, D. en Turic, L. (1980). Eine andere Variante von selbstgeführten Stromrichtern. ETZ-Archiv, 2, 325-326.

7. Case, M.J. (1980). A direct ac to ac regenerative frequency and voltage converter. Ph.D. thesis, Dept. Elec. Eng, Univ. Cape Town.

8. Von Schlotheim, G. (1971). Untersuchungen an einem neuen zwangskommutierten Direktumrichter zur Speisung ein-oder mehrphasiger Verbraucher (Diss. Fak. Elektrotechnik. TH Darmstadt).

9. Hull, A.W. (1929). Hot-cathode thyratrons. G.E. Review, 32 (7), 390-399.

10. Tompkins F.N. (1932). The parallel type inverter, AIEE. Trans., 51, 707-714.

11. Rissik, H. (1935). Mercury-arc current converters. London, Pitman.

12. Van Wyk, J.D. (1970). Power and machine electronics 1914-1966. Monografie, S.A. Inst. v. Elektriese Ingenieurs, Johannesburg.

13. Kehrmann, H.W., Lienau, W. en Nill, R. (1974). Vierquadrantensteller einde netzfreundliche Einspeisung für Triebfahrzeuge mit Drehstromantrieb. Elektrische Bahnen, 45, $135-141$. 